\title{
PROVISION OF CHILDREN'S TOURIST GROUPS WITH FUNCTIONAL DRINKS
}

* Kristina BELINSKA

KamianetsPodilskyi National Ivan Ohiienko University, Suvorova str., 52, Kamianets Podilskyi, Ukraine, 32300

kristina0612@ukr.net

*Corresponding author

Received $18^{\text {th }}$ October 2020, accepted 30 $0^{\text {th }}$ March 2021

\begin{abstract}
One of the main components of tourism is to provide tourist groups with a balanced diet. In addition to nutrition, drinking balance is important too. Sweet carbonated drinks, which do not benefit the child's health, are especially common among children's tourist groups. Therefore, it is advisable to develop drinks for children's tourist groups, which are characterized by useful properties, are tasty and have not a tendency to microbiological spoilage. The presented researches suggest developing milk dry drinks. However, it was proposed to use powdered sheep milk as a basis, because sheep milk powder contains much more essential substances needed by the child's body than cow milk. It is known that a significant number of children do not consume milk due to taste preferences. Therefore, it was proposed to add cryopowders to the drink as an additional source of vitamins and minerals and as a flavor enhancer. In this work the research on establishment of a rational dosage of cryopowders to a compounding of dry drinks was carried out. Sensory analysis and mathematical calculations showed that the rational dosage of cryopowders to the formulation was 10\%. It was found that adding cryopowders to the milk drink improved taste of the finished product. In addition, the use of cryopowders increased children's daily intake of vitamins and minerals. After conducted researches the terms at which the restored products are appropriate for consumption and do not carry the threat of food poisoning were established.
\end{abstract}

Keywords: milk drink, cryopowder, nutritional value, sheep milk.

\section{Introduction}

Children's tourism is one of the most constant parts of the market of any country. However, the organization of children's recreation has its own specifics, requires special attention and careful preparation [1].

During the tourist trip it is important to provide children's groups with a balanced diet. Today, many restaurants provide catering services for children's tourist groups. But the important fact remains that children need small snacks and drinks between main meals.

During a tourist trip, the best product for regulating the water balance in the body is water. However, most children prefer carbonated sweet drinks and canned juice.
It is known that such products are not useful for the body. And at a high temperature of the environment, which is typical for the summer period - vacation time and the most favorable time for travel, there is microbiological spoilage of products.

To solve this problem, it is necessary to explore possible ways to enrich children's drinks, justify the choice of the main component for drinks and explore the maximum possible expiration date of the restored product.

Of course, the most useful drink is milk. Milk contains almost all known vitamins and minerals [2]. Cow milk is commonly consumed, but other types of milk are much richer in substances which are essential for the baby's body. Therefore, 
for the preparation of beverages, it was proposed to use sheep's milk as a basis.

But the use of milk during travel due to the threat of microbiological spoilage is possible only in dry form. Therefore, the development of a milk drink for children's tourist groups based on milk powder was envisaged.

Compared to cow's milk powder, sheep's milk powder contains 9\% more animal protein, more linoleic acid and twice more linolenic acid, 4.5 times more lactoferrin. In addition, sheep's milk powder contains twice more ascorbic acid than cow's milk powder, 1.6 times more thiamine and 4.6 times more nicotinic acid [3].

However, there was another problem - a large number of children do not consume milk due to taste preferences. But at the same time they like milkshakes with flavors of tropical and domestic fruit.

In addition, milk powder is characterized by poorer vitamin composition than liquid milk [4]. Therefore, an important task was to develop milk drinks for children's tourist groups, which will be safe for children, will provide the child's body with essential substances and, most importantly, be delicious.

In recent years, cryopowders have become very popular [5]. Authors Peresichny M.,
Korzun V. [6] showed that the introduction of various types of cryopowders in the form of fillers in fermented milk drinks allowed creating new types of drinks with therapeutic and prophylactic action, which had delicious taste and high sensory characteristics. The use of cryopowders for sweet dishes and products allowed enriching them with vitamins, minerals, dietary fiber. Due to their use, the chemical composition of food products was significantly improved and their biological value increased. These data allowed recommending cryopowders for use in production of dairy products.

\section{Matherials and methods}

Sheep milk powder, cow milk powder, apricot, blackberry and raspberry cryopowders were used for the study. The chemical composition of cryopowders is presented in Table 1.

Experimental studies included the search for and identification of rational ratios of components - milk base and cryopowder, study of organoleptic, technological indicators of finished beverages, assessment of their biological and nutritional value.

Chemical composition of cryopowders $[7,8]$

\begin{tabular}{|l|l|l|l|}
\hline \multirow{2}{*}{ Indicator } & \multicolumn{3}{c|}{ Cryopowder from } \\
\cline { 2 - 4 } & \multicolumn{1}{|c|}{ apricot } & \multicolumn{1}{c|}{ blackberry } & \multicolumn{1}{c|}{ raspberry } \\
\hline Cellulose, $\mathrm{g}$ & 15.3 & 35.0 & 27.14 \\
\hline Vitamin content, $\mathrm{mg} / 100 \mathrm{~g}$ & 63.0 & 89.0 & 133.0 \\
\hline $\mathrm{C}$ & 0.1 & 0.1 & 0.11 \\
\hline $\mathrm{B}_{1}$ & 0.2 & 0.4 & 0.27 \\
\hline $\mathrm{B}_{2}$ & 4.0 & 9.0 & 3.2 \\
\hline $\mathrm{PP}$ & 1870 & 420 & 1193 \\
\hline $\mathrm{The}$ content of mineral substances, $\mathrm{mg} / 100 \mathrm{~g}$ & 213 \\
\hline $\mathrm{K}$ & 160 & 390 & 117 \\
\hline $\mathrm{Ca}$ & 170 & 320 & 197 \\
\hline $\mathrm{Mg}$ & 3 & 89 & \\
\hline $\mathrm{P}$ & &
\end{tabular}

Kristina BELINSKA, Provision of children's tourist groups with functional drinks, Food and Environment Safety, Volume XX, Issue $1-2021$, pag. $43-48$ 


\section{Results and discussion}

Organoleptic quality indicators of restored dried dairy products with cryopowders from apricot, blackberry and raspberry were determined in the study. The results of the study are presented in Table 2 .

Table 2

Sensory characteristics of restored beverages

\begin{tabular}{|c|c|c|c|c|}
\hline $\begin{array}{l}\text { Dosage of } g \\
\text { cryopowder / } 100 \\
g \text { of the mixture }\end{array}$ & Consistence & Color & Taste & Flavor \\
\hline \multicolumn{5}{|c|}{ with cryopowder from apricot } \\
\hline 5 & \multirow[t]{3}{*}{ Liquid } & $\begin{array}{l}\text { Slightly pronounced orange } \\
\text { hue }\end{array}$ & $\begin{array}{l}\text { Slightly palpable } \\
\text { apricot }\end{array}$ & \multirow[t]{2}{*}{$\begin{array}{l}\text { Slightly noticeable } \\
\text { aroma of apricot }\end{array}$} \\
\hline 10 & & Pale orange & $\begin{array}{l}\text { Moderately rich } \\
\text { pleasant apricot }\end{array}$ & \\
\hline 15 & & Rich pale orange & Too rich apricot & Rich aroma \\
\hline \multicolumn{5}{|c|}{ with cryopowder from blackberry } \\
\hline 5 & \multirow[t]{3}{*}{ Liquid } & Lilac & \multirow{2}{*}{$\begin{array}{l}\text { Moderately rich } \\
\text { pleasant blackberry }\end{array}$} & \multirow{2}{*}{$\begin{array}{l}\text { Slightly noticeable } \\
\text { aroma of blackberry }\end{array}$} \\
\hline 10 & & Pale purple & & \\
\hline 15 & & Deep purple with a red tinge & $\begin{array}{l}\text { Oversaturated with a } \\
\text { sour taste }\end{array}$ & Prominent \\
\hline \multicolumn{5}{|c|}{ with cryopowder from raspberry } \\
\hline 5 & \multirow[t]{3}{*}{ Liquid } & Pale pink & \multirow{2}{*}{$\begin{array}{l}\text { Moderately rich } \\
\text { pleasant raspberry }\end{array}$} & \multirow{2}{*}{$\begin{array}{l}\text { Slightly noticeable } \\
\text { aroma of raspberries }\end{array}$} \\
\hline 10 & & Pale pink & & \\
\hline 15 & & Deep pink & $\begin{array}{l}\text { Oversaturated with a } \\
\text { sour taste }\end{array}$ & Prominent \\
\hline
\end{tabular}

It was recommended to restore the dry mixture with drinking water at a temperature of $18-40^{\circ} \mathrm{C}$ depending on the season. According to the recommendations for the restoration of milk powder, the dry drink was to be restored in the ratio - 1:10. Studies indicated that increasing the dosage of cryopowders increased the intensity of taste, color and odor, and therefore the quality of finished drinks deteriorated.

In the following experiment, changes in the chemical composition of dry milk drinks were determined depending on the amount of added cryopowder. The results are presented in Table 3.

Table 3

Chemical composition of dry milk drinks with cryopowders

\begin{tabular}{|c|c|c|c|c|c|c|c|c|c|}
\hline \multirow{3}{*}{$\begin{array}{l}\text { Component, } \\
\mathrm{mg} / 100 \mathrm{~g}\end{array}$} & \multicolumn{9}{|c|}{ Cryopowder, per $100 \mathrm{~g}$ of dry mixture } \\
\hline & \multicolumn{3}{|c|}{ apricot } & \multicolumn{3}{|c|}{ blackberry } & \multicolumn{3}{|c|}{ raspberry } \\
\hline & $5 \%$ & $10 \%$ & $15 \%$ & $5 \%$ & $10 \%$ & $15 \%$ & $5 \%$ & $10 \%$ & $15 \%$ \\
\hline Cellulose, $\mathrm{g}$ & 0.77 & 1.53 & 2.3 & 1.8 & 3.5 & 5.3 & 1.4 & 2.7 & 4.1 \\
\hline $\mathrm{C}, \mathrm{mg} / 100 \mathrm{~g}$ & 9.8 & 12.6 & 15.4 & 11.1 & 15.2 & 19.3 & 13.3 & 19.6 & 25.9 \\
\hline $\mathrm{B}_{1}, \mathrm{mg} / 100 \mathrm{~g}$ & 0.31 & 0.3 & 0.29 & 0.31 & 0.3 & 0.29 & 0.31 & 0.3 & 0.29 \\
\hline $\mathrm{B}_{2}, \mathrm{mg} / 100 \mathrm{~g}$ & 0.82 & 0.79 & 0.75 & 0.83 & 0.81 & 0.78 & 0.82 & 0.79 & 0.76 \\
\hline $\mathrm{PP}, \mathrm{mg} / 100 \mathrm{~g}$ & 3.24 & 3.28 & 3.32 & 3.49 & 3.78 & 4.07 & 3.2 & 3.2 & 3.2 \\
\hline $\mathrm{K}, \mathrm{mg} / 100 \mathrm{~g}$ & 93.8 & 187.29 & 280.77 & 21.3 & 42.29 & 63.27 & 59.95 & 119.59 & 179.22 \\
\hline $\mathrm{Ca}, \mathrm{mg} / 100 \mathrm{~g}$ & 8.85 & 16.8 & 24.76 & 20.35 & 39.8 & 59.26 & 11.5 & 22.1 & 32.7 \\
\hline $\mathrm{Mg}, \mathrm{mg} / 100 \mathrm{~g}$ & 8.57 & 17.07 & 25.56 & 16.07 & 32.07 & 48.06 & 5.92 & 11.77 & 17.61 \\
\hline $\mathrm{P}, \mathrm{mg} / 100 \mathrm{~g}$ & 0.56 & 0.69 & 0.82 & 4.86 & 9.29 & 13.72 & 10.26 & 20.09 & 29.92 \\
\hline
\end{tabular}

According to the conducted researches it was established that with increase in a dosage of cryopowders the maintenance of essential substances in a finished product increased. Consequently, the chemical composition of the finished products improved.

Kristina BELINSKA, Provision of children's tourist groups with functional drinks, Food and Environment Safety, Volume XX, Issue 1 - 2021, pag. $43-48$ 
Therefore, it was rational to add cryopowders to the mixture.in the amount of $10 \%$ to milk powder.

However, it was necessary to calculate the ability of the developed products to meet the daily requirement of essential substances. For this purpose, it was proposed to make calculations per portion of the finished dish.

Since the primary goal of creating a product was to provide healthy drinks for children's tourist groups, and therefore the portion should be calculated for one consumption by one child, that is per one glass (Table 4). Therefore, when restoring the product in a ratio of $1: 10$, the weight of the dry mixture was taken per serving in the amount of $20 \mathrm{~g}$, the weight of water $200 \mathrm{~g}$. Therefore, further calculation was performed per one serving of dry drink. The daily requirement was taken into account for children aged 7-10 years. [9]

Thus, the expediency of using cryopowders from apricot, blackberry, and raspberry in the technology of dry milk drinks, which increased their biological value, was substantiated.

The next stage of research was to determine the acidity of the drink after restoration and during storage (Fig. 1). For this purpose, the dry beverage was restored with water (the temperature of $22{ }^{\circ} \mathrm{C}$ ) at the temperature of the environment - 22 ${ }^{0} \mathrm{C}$. The acidity of the drink indicated its freshness and safety. Sheep's milk was considered unfit for consumption in its native form with an acidity above $24{ }^{0} \mathrm{~T}$ [10].

The results of the study indicated that cryopowders increased the acidity of the drink by 1 degree. It was found that after 3 hours after preparing, drinks with cryopowders from raspberry and blackberry were not appropriate for consumption. The acidity of these drinks exceeded the permissible norm. The suitability of the drink with cryopowder from apricot for consumption after 3 hours after preparation was due to the fact that the acidity of cryopowder from apricot was lower compared to other cryopowders.

Table 4

\begin{tabular}{|c|c|c|c|c|c|c|}
\hline \multirow[b]{3}{*}{ Component } & \multicolumn{6}{|c|}{ Dry drink based on sheep milk with cryopowder from } \\
\hline & \multicolumn{2}{|c|}{ apricot } & \multicolumn{2}{|c|}{ blackberry } & \multicolumn{2}{|c|}{ raspberry } \\
\hline & $\begin{array}{l}\text { Content } \\
\text { per } \\
\text { serving }\end{array}$ & $\begin{array}{l}\text { Satisfaction of } \\
\text { daily needs, } \%\end{array}$ & $\begin{array}{l}\text { Content } \\
\text { per } \\
\text { serving }\end{array}$ & $\begin{array}{l}\text { Satisfaction of } \\
\text { daily needs, \% }\end{array}$ & $\begin{array}{l}\text { Content } \\
\text { per } \\
\text { serving }\end{array}$ & $\begin{array}{l}\text { Satisfaction of } \\
\text { daily needs, \% }\end{array}$ \\
\hline $\begin{array}{l}\text { Animal proteins, } \\
\mathrm{g}\end{array}$ & 4.5 & 8.8 & 4.5 & 8.8 & 4.5 & 8.8 \\
\hline Fats, $\mathrm{g}$ & 5.76 & 8.2 & 5.76 & 8.2 & 5.76 & 8.2 \\
\hline Carbohydrates, $\mathrm{g}$ & 3.78 & 1.3 & 3.78 & 1.3 & 3.78 & 1.3 \\
\hline Linoleic acid, g & 0.7 & 5.8 & 0.07 & 5.8 & 0.07 & 5.8 \\
\hline Linolenic acid, $g$ & 0.04 & 20.0 & 0.04 & 20.0 & 0.04 & 20.0 \\
\hline Lactoferrin, $g$ & 0.13 & - & 0.13 & - & 0.13 & - \\
\hline Cellulose, $\mathrm{g}$ & 0.31 & 1.6 & 0.7 & 3.5 & 0.54 & 2.7 \\
\hline $\mathrm{C}, \mathrm{mg}$ & 2.52 & 4.2 & 3.04 & 5.1 & 3,92 & 6.5 \\
\hline $\mathrm{B}_{1}, \mathrm{mg}$ & 0.06 & 6.0 & 0.06 & 6.0 & 0.06 & 6.0 \\
\hline $\mathrm{B}_{2}, \mathrm{mg}$ & 0.16 & 13.3 & 0.16 & 13.3 & 0.16 & 13.2 \\
\hline $\mathrm{PP}, \mathrm{mg}$ & 0.66 & 4.4 & 0.76 & 5.1 & 0.64 & 4.3 \\
\hline $\mathrm{K}, \mathrm{mg}$ & 37.46 & 5.0 & 8.46 & 1.2 & 23.92 & 3.2 \\
\hline $\mathrm{Ca}, \mathrm{mg}$ & 3.36 & 0.34 & 7.96 & 0.8 & 4.42 & 0.4 \\
\hline $\mathrm{Mg}, \mathrm{mg}$ & 3.4 & 2.0 & 6.41 & 3.8 & 2.35 & 1.4 \\
\hline $\mathrm{P}, \mathrm{mg}$ & 0.14 & 0.01 & 1.86 & 0.2 & 4.02 & 0.4 \\
\hline
\end{tabular}

Kristina BELINSKA, Provision of children's tourist groups with functional drinks, Food and Environment Safety, Volume $\mathrm{XX}$, Issue $1-2021$, pag. $43-48$ 
In summer, when the temperature of the environment is about $30^{\circ} \mathrm{C}$ or even higher, the accumulation of acidity in beverages is more intense. Therefore, it was recommended to use the investigated drinks immediately after preparing and no later than 30 minutes after preparing.
Since these drinks were designed for children's tourist groups, it was proposed to produce these products packaged in plastic bags for every portion. This packaging will be convenient when preparing drink while traveling.

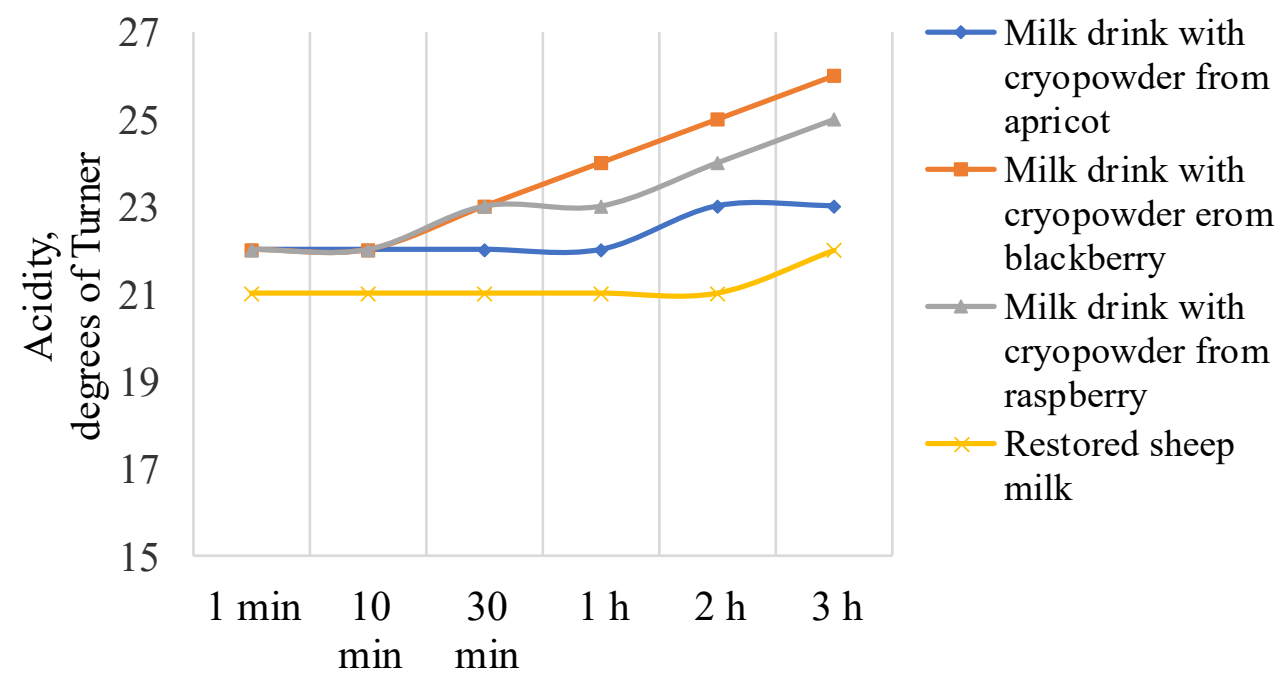

Time after restoration

Fig. 1. Acidity of drinks after restoration

\section{Conclusion}

As a result of the conducted researches it was established that:

- the addition of cryopowders to milk powder led to an improvement of the organoleptic characteristics of the restored drink: the taste and aroma improved, a pleasant color appeared;

- the use of powdered sheep's milk as a basis for the drink increased the nutritional value: the amount of animal fats increased, the amount of polyunsaturated fatty acids increased, the amount of lactoferrin increased;

- production of milk drink with cryopowders improved the chemical composition: the daily requirement of vitamins and minerals was covered by $0.4 \ldots 13.2 \%$;
- the use of cryopowders in the technology of dry milk drinks allowed covering the daily requirement of dietary fiber by $1.6 \ldots$ $3.5 \%$;

- cryopowders affected the acidity of the restored beverage. Therefore, it was established that the drink should be consumed immediately after preparing and no later than 30 minutes after preparing.

\section{References}

[1] IVCHENKO L., KUZHYL S., PETRENKO M. Features of children's tourism organization in Ukraine, Ekonomika ta derzhava, 1: 83-88, (2019). DOI: $10.32702 / 2306-6806.2019 .1 .83$

[2] SERIKOVA A., SMOLNIKOVA F., REBEZOV M., OKUSKHANOVA E., TEMERBAYEVA M., GORELIK O.. Development of technology of fermented milk drink with immune stimulating properties. Research journal of pharmaceutical, biological and chemical sciences, 9 (4): 495-500, (2018).

Kristina BELINSKA, Provision of children's tourist groups with functional drinks, Food and Environment Safety, Volume $\mathrm{XX}$, Issue $1-2021$, pag. $43-48$ 
[3] BELINSKA K. FALENDYSH N. Perspectives of using sheep's milk in baby food, Research papers of the National University of Food Technologies, 21 (4): 231-236, (2015).

[4] Nadykta, V.D., Shcherbakova, E.V., Olkhovatov, E.A. (2017). Technology of powdered food additives. Polythematic network electronic scientific journal of the Kuban State Agrarian University, no. 131, pp. 659--671.

[5] MANSUROV A., BOCHAROV V., PALCHIKOV V., RATUSHNY A. Impact cryopowder 'Apple' on the quality of whey beverage functional purpose, Technologies of food and processing industry of AIC - healthy food, 1: 48-55. (2019).

[6] Hachak, U., \&Vavrysevych, J. THE USE OF CRYOPOWDER «PUMPKIN» IN THE TECHNOLOGY OF CHEESE MASSES WITH DIFFERENT FAT CONTENT. Scientific Messenger of LNU of Veterinary Medicine and Biotechnologies. Series: Food Technologies 18 (2): 41-45, (2016). https://doi.org/10.15421/nvlvet6808
[7] YARALIEVA Z., Sovershenstvovanietechnologiikrioporoshkovizplod oviyagod, vyrashchyvaiemych v predgornychrayonachDagestana. Kand, Diss. [Improving the technology of cryopowders from fruits and berries grown in the foothill regions of Dagestan]. Krasnodar, 2017. 141

[8] Kasyanov, G.I., Yaralieva, Z.A., Akhmedov, M.E. (2018). Fruit and berry cryopowder technology. Krasnodar: Ecoinvest, 155 p.

[9] About the statement of Norms of physiological needs of the population of Ukraine in the basic nutrients and energy. Document z1206-17, September, 3, 2017. Verchovna Rada of Ukraine. Legislation of Ukraine, (2017). Available at: https://zakon.rada.gov.ua/laws/show/z1206-

17?lang=en\#Text

[10] BALTHAZARA CF, SILVA HLA, VIEIRA AH, NETO RPC, CAPPATO LP, COIMBRA PT.Assessing the effects of different prebiotic dietary oligosaccharides in sheep milk ice cream. Food Res Int91:38-46. (2017)

Kristina BELINSKA, Provision of children's tourist groups with functional drinks, Food and Environment Safety, Volume XX, Issue $1-2021$, pag. $43-48$ 